\title{
PENGEMBANGAN BUKU PENGAYAAN PENGETAHUAN “KAJIAN FISIS BATUBARA" UNTUK SISWA SMA
}

\author{
Mia Andina Lubis ${ }^{1, *}$, Desnita $^{2}$, A. Handjoko Permana ${ }^{3}$ \\ Program Studi Pendidikan Fisika, Fakultas Matematika dan Ilmu Pengetahuan Alam, Universitas Negri Jakarta, Jalan \\ Rawamangun Muka No. 1 Jakarta Timur, 13220. \\ ${ }^{*}$ mia.andina@gmail.com
}

\begin{abstract}
Abstrak
Penelitian ini bertujuan mengembangkan buku pengayaan pengetahuan "Kajian Fisis Batubara" yang layak untuk SMA. Buku ini ditujukan untuk siswa yang tuntas menguasai materi pelajaran fisika pada Kompetensi Dasar memahami keterbatasan sumber daya energi dan dampaknya bagi kehidupan. Metode Penelitian yang digunakan adalah Research and Development dan mengacu pada model pengembangan ADDIE (Analysis, Design, Development, Implementation, and Evaluation). Instrumen penilaian produk dan respon siswa berupa lembar angket yang terdiri atas 4 komponen yaitu kelayakan materi, penyajian, bahasa, dan grafika. Instrumen penilaian yang digunakan berpedoman pada instrumen penilaian buku pengayaan pengetahuan yang diterbitkan oleh Pusat Kurikulum dan Perbukuan (Puskurbuk). Buku ditulis dengan bahasa komunikatif dilengkapi dengan gambar menarik, data serta info faktual batubara. Hasil uji kelayakan oleh ahli materi $92 \%$, pembelajaran $89,3 \%$ dan grafika 83,3\% dengan interpretasi "sangat baik", sedangkan ahli media 80,5\% dengan interpretasi "baik". Berdasarkan uji efektivitas diperoleh skor gain 0,35 , menunjukkan bahwa buku pengayaan dapat meningkatkan pengetahuan siswa dengan kategori sedang. Berdasarkan uji kelayakan dan uji efektivitas dapat disimpulkan buku pengayaan pengetahuan "kajian Fisis Batubara" dinyatakan layak sebagai buku pengayaan pengetahuan dan dapat meningkatkan pengetahuan siswa.
\end{abstract}

Kata Kunci:Buku Pengayaan Pengetahuan, Sumber Energi, Batubara

\begin{abstract}
This study was conducted to develop the standardized knowledge-enrichment book for Senior High School Students. This book was tended to the students who have completely mastered the Physics materials in comprehending the limitation of energy sources and its effect for human's life, as stated in the Main Competency (Kompetensi Dasar) of the existing Curriculum. The research method used is Research and Development which refers to ADDIE Development Model (Analysis, Design, Development, Implementation, and Evaluation). Questionnare was given as the assessment-instrument of the study which consists of four indicators; material, language, presentation, and graphic. The standard of assessment-instrument used in this study was in line with the standard of assessment-instrument of knowledge-enrichment book by Pusat Kurikulum dan Perbukuan (Puskurbuk) of Indonesian Ministry of Education and Culture. Written in communicative language, interactive pictures, and simplistic explanation about factual information of coal, the book acquired $92 \%$ of material-standard, $89.3 \%$ of activity-standard, and $83,3 \%$ graphic-standard with the "very good" intepretation, while $80.5 \%$ for media-standard with the "good" intepretation. Based on the efficacy-standard testing, the book had 0.35 gain-score, indicated that it can enhance students' knowledge in the 'middle' category. The result strengthened that the knowledge-enrichment book "Kajian Fisis Batubara" was appropriate as a standardized and well-intepreted book.
\end{abstract}

Keywords :Knowledge-enrichment book, Energy sources, Coal.

\section{Pendahuluan}

Energi merupakan komponen penting yang tidak dapat dilepaskan dalam kelangsungan hidup manusia.
Saat ini, hampir semua aktivitas kehidupan manusia sangat tergantung pada ketersediaan energi terutama sumber energi batubara yang dapat memenuhi kebutuhan energi manusia dalam skala yang besar. 
Namun, beberapa tahun mendatang penggunaan energi yang berlebihan akan menyebabkan terjadinya masalah kekurangan sumber energi atau krisis energi. Populasi manusia yang terus bertambah mengakibatkan permintaan terhadap energi semakin meningkat. Manusia akan dihadapkan pada situasi semakin menipisnya cadangan sumber energi batubara dan meningkatnya kerusakan lingkungan yang terjadi akibat penggunaan batubara.

Batubara adalah sedimen batuan organik yang mudah terbakar dan terbentuk dari sisa-sisa tumbuhan selama periode waktu yang panjang (puluhan hingga berjuta tahun lamanya). Dengan pengaruh tekanan dan mikroba disertai beberapa peristiwa kimia dan fisika ataupun keadaan geologi sisa-sisa tumbuhan ini akan hancur, menggumpal, bersatu dengan lainnya dan akhirnya membentuk sedimen batuan organik yang disebut batubara.

Sumber energi batubara banyak diminati terutama di bidang industri contohnya pembangkit listrik tenaga uap (PLTU) dengan batubara sebagai bahan bakar utamanya. Instalasi pembangkit listrik menggunakan mesin turbin dengan menghasilkan energi listrik dengan bahan bakar batubara. PLTU batubara sendiri adalah sumber utama listrik dunia saat ini. Sekitar $60 \%$ listrik dunia bergantung pada batubara karena biaya PLTU batubara sangat terjangkau.

Batubara mempunyai empat sifat umum yaitu peat, lignite, sub-bituminous, bituminous, dan anthracite. Bahan bakar yang digunakan pada PLTU adalah subbituminous dan bituminous yang nilai kalornya 4200$6900 \mathrm{Kcal} / \mathrm{kg}$. Sumber energi batubara termasuk ke dalam energi tak terbarukan dimana ketersediaannya terbatas, dan apabila habis tidak dapat diperbaharui kembali. Masyarakat dinilai perlu untuk mengetahui tentang sumber energi batubara, mengingat sumber energi batubara ini sangat penting di kehidupan sehari-hari dan menyangkut hidup orang banyak. Jika masyarakat mengetahui pengetahuan tentang batubara, maka dalam menggunakannya bisa lebih hemat menggunakan listrik dan menyadari akan pentingnya batubara sebagai sumber energi tak terbarukan.

Selain masyarakat, pelajar juga membutuhkan sumber informasi mengenai sumber energi batubara. Hal ini sesuai dengan prinsip belajar di sekolah yang sebelumnya guru menjadi satu-satunya sumber belajar, berubah menjadi belajar berbasis aneka sumber belajar. Bagi peserta didik yang telah memenuhi standar kompetensi, dapat dilaksanakan program pengayaan (enrichment). Menurut Permendiknas RI Nomor 2 tahun 2008 pasal 6 ayat 3 menyatakan bahwa pendidik dapat menganjurkan peserta didik untuk membaca pengayaan dan buku referensi untuk menambah pengetahuan dan wawasan peserta didik.

Buku pengayaan merupakan buku yang memuat materi yang dapat memperkaya dan meningkatkan penguasaan IPTEK, keterampilan, membentuk kepribadian peserta didik, guru, pengelola pendidikan, dan masyarakat lainnya. Buku pengayaan termasuk ke dalam buku nonteks pelajaran yang berisi materi pendukung dan pelengkap buku teks pelajaran. Salah satu jenis buku pengayaan yaitu buku pengayaan pengetahuan yang memuat materi yang dapat memperkaya dan meningkatkan penguasaan ipteks. Ciri-ciri buku pengayaan pengetahuan adalah (1) Materi/isi buku bersifat kenyataan, (2) Pengembangan isi tulisan tidak terikat pada kurikulum, (3) Pengembangan materi bertumpu pada perkembangan ilmu terkait, (4) Bentuk penyajian berupa deskriptif dan dapat disertai gambar, (5) Penyajian isi buku dilakukan secara popular.

Guna memenuhi kebutuhan masyarakat dan pelajar, guru sebagai fasilitator memiliki kewajiban memfasilitasi proses pembelajaran, salah satunya adalah memfasilitasi siswa untuk membaca buku pengayaan. Buku pengayaan yang telah dibuat perlu diteliti kelayakannya sebagai bahan ajar program pengayaan untuk siswa SMA.

\section{Metode Penelitian}

Metode yang digunakan dalam penelitian ini adalah metode penelitian dan pengembangan. Model yang diterapkan yaitu penelitian pengembangan ADDIE yang meliputi lima tahap, yaitu Analysis (analisis), Design (perencanaan), Development (pengembangan), Implementation (implementasi), dan Evaluation (evaluasi). Fokus penelitian adalah mengembangkan buku pengayaan pengetahuan yang layak tentang kajian fisis batubara. Untuk melakukan uji kelayakan maka disusun lembar validasi berupa angket berdasarkan instrumen penilaian oleh pusat kurikulum dan perbukuan (Puskurbuk). Kelayakan buku divalidasi oleh beberapa validator atau penguji kelayakan.

\section{Hasil dan Pembahasan}

\section{a. Studi Pendahuluan}

Studi pendahuluan dilakukan di beberapa sekolah dan toko buku ternama di jakarta. Berdasarkan survei ke sekolah belum ditemukan buku pengayaan yang membahas secara khusus mengenai sumber energi batubara, selain itu, hasil survei didapatkan $50 \%$ sekolah mempunyai buku pengayaan di bidang IPA dan 50\% dari sekolah yang diobservasi belum memenuhi kebutuhan siswa dalam memfasilitasi buku pengayaan untuk proses pembelajaran.

Observasi lainnya dilakukan pada penerbit dan toko buku ternama di jakarta. Dan berdasarkan observasi yang sudah dilakukan, belum ditemukan buku 
pengayaan pengetahuan yang membahas khusus batubara.

\section{b. Buku pengayaan pengetahuan}

Hasil penelitiaan ini berupa buku pengayaan pengetahuan yang membahas tentang konsep fisis batubara. Buku pengayaan ini terdiri dari enam bab yaitu pada bab 1 pendahuluan berisi pengetahuan umum tentang definisi batubara dan sifat-sifat umumnya, bab dua berisi tentang pembentukan batubara, bab tiga berisi tentang sifat fisika dan kimia batubara, bab empat berisi karakterisasi batubara, bab lima berisi pemanfaatan dan dampak penggunaan batubara, dan bab terkahir berisi sumber energi sederhana pengganti batubara.

Konsep fisis pada batubara dimana pada pembagianpembagian sifat umum berdasarkan nilai kalor, pembentukan batubara yang dipengaruhi oleh tekanan, suhu, dan waktu, sifat fisika yaitu mempunyai massa jenis dan mempunyai nilai kalor, dan pada saat batubara dimanfaatkan untuk pembangkit listrik tenaga uap sebagai bahan bakar dapat menjadi energi listrik.

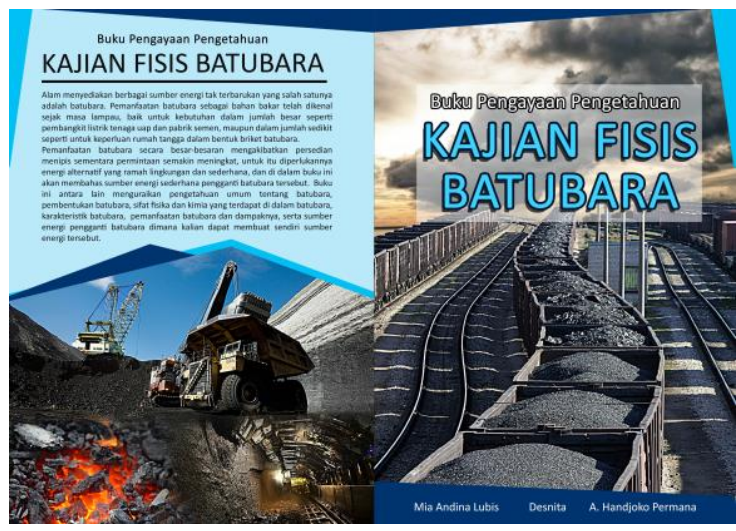

Gambar 1.Tampilan cover depan dan belakang buku pengayaan

Isi buku pengayaan terdapat beberapa komponen dalam buku yang membedakan dengan buku lain seperti "info kecil" yang berisi informasi-informasi yang belum diketahui sebelumnya seperti peristiwa besar, kosa kata ilmiah atau fakta-fakta menarik yang berhubungan dengan batubara, selain itu terdapat "mari mencoba" dimana berisi percobaan sederhana yang mengajak pembaca untuk melakukan kegiatan yang diperintahkan, mengenai aplikasi perhitungan dan gagasan-gagasan dalam lingkungan hidup. Buku ini berisi gambar-gambar di setiap halamannya yang membuat pembaca merasa tertarik dan termotivasi untuk belajar. Bahasa yang digunakan menggunakan bahasa yang komunikatif sehingga pembaca tidak merasa bosan.

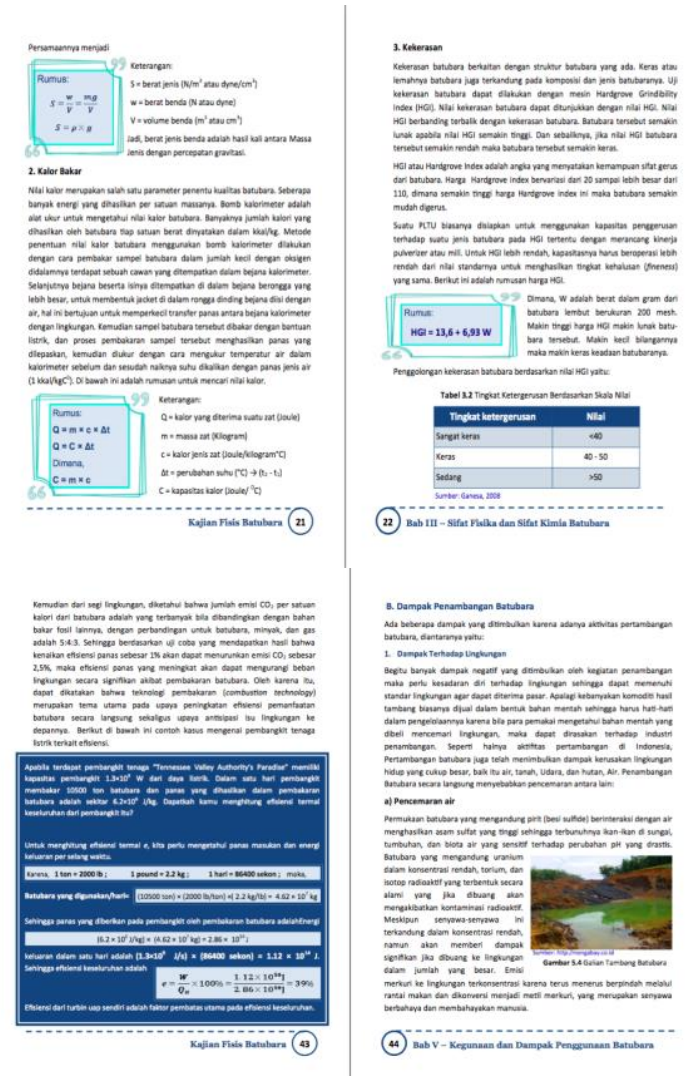

Gambar 2. Contoh isi buku pengayaan

\section{c. Uji kelayakan}

Buku pengayaan pengetahuan yang sudah dikembangkan diuji kelayakannya kepada empat orang ahli, yakni ahli materi, media, pembelajaran dan grafika. Penilaian dan saran dari para ahli akan menjadi bahan pertimbangan untuk merevisi dan memperbaiki buku "Kajian Fisis Batubara" sehingga produk yang dihasilkan memiliki kualitas yang lebih baik lagi. Adapun hasil skor untuk masing-masing para ahli, yaitu:

Tabel 1. Hasil Uji Kelayakan

\begin{tabular}{|c|c|c|}
\hline No. & Ahli & Rata-Rata skor \\
\hline 1. & Materi & $92 \%$ \\
\hline 2. & Media & $80,5 \%$ \\
\hline 3. & Pembelajaran & $89,3 \%$ \\
\hline 4. & Grafika & $83,3 \%$ \\
\hline
\end{tabular}

Berdasarkan hasil uji kelayakan oleh beberapa ahli diperoleh interpretasi "Baik" sampai dengan "Sangat Baik" sehingga dapat diperoleh buku pengayaan pengetahuan "Kajian Fisis Batubara" yang dikembangkan dinyatakan layak sebagai sebagai sumber belajar. 


\section{Uji coba Pengguanaan Produk}

Uji coba produk melibatkan 15 orang siswa kelas XI dan XII SMA Negeri 12 Jakarta dengan menggunakan instrumen yang telah dibuat sebelumnya. Uji coba dilakukan untuk mengetahui keefektifan buku pengayaan dalam proses pembelajaran serta pendapat peserta didik mengenai buku pengayaan pengetahuan Kajian Fisis Batubara. Berdasarkan uji coba penggunaan produk, diperoleh presentase untuk masing-masing komponen, yaitu:

Tabel 2. Hasil Uji Coba Pengguanaan produk

\begin{tabular}{|c|c|c|}
\hline No. & Komponen & $\begin{array}{c}\text { Rata-Rata } \\
\text { skor }\end{array}$ \\
\hline 1. & Materi & $81,3 \%$ \\
\hline 2. & Bahasa & $73,7 \%$ \\
\hline 3. & Penyajian & $83,1 \%$ \\
\hline
\end{tabular}

Selanjutnya, untuk mengetahui efektivitas buku maka dilakukan uji coba produk. Uji coba dilakukan oleh 15 orang kelas XI dan XII yang telah mengetahui konsep sumber energi batubara. Untuk materi sumber energi seharusnya diujicobakan kepada siswa kelas XII yang sudah mempelajarinya pada bab terkahir, tetapi dikarenakan kondisi yang sudah tidak memungkinkan maka diujicobakan ke kelas XI dengan syarat sudah mengetahui sumber energi batubara secara umum. Sebelum membaca buku, para peserta didik diminta untuk mengerjakan pre test berupa soal pilihan ganda sebanyak 10 soal. Setelah mengerjakan pre test peserta didik diminta untuk membaca buku dan berdiskusi dengan teman sebangkunya. Di akhir pembelajaran peserta didik mengerjakan post test berupa soal pilihan ganda sebanyak 10 soal dengan tingkat kesukaran yang sama dengan pre test. Setelah post test peserta didik diminta mengisi angket untuk mengetahui pendapatnya mengenai buku pengayaan yang telah dibaca. Berdasarkan hasil pre test dan post test disimpulkan terdapat peningkatan pengetahuan peserta didik setelah pembelajaran. Hal ini dibuktikan dengan uji gain yang memperoleh hasil 0,35. Dari hasil yang didapat dapat disimpulkan bahwa buku pengayaan pengetahuan yang dikembangkan dapat menambah pengetahuan peserta didik dengan kategori "sedang".

\section{Kesimpulan}

Pada penelitian ini telah berhasil dikembangkan buku pengayaan pengetahuan yang berjudul kajian fisis batubara dan hasil yang didapat dari hasil validasi beberapa ahli dapat disimpulkan bahwa buku pengayaan pengetahuan layak dijadikan sebagai sumber belajar pendukung di SMA dan dapat meningkatkan menambah pengetahuan peserta didik

\section{Daftar Acuan}

[1] Aladin, Andi. 2011. Sumber Daya Alam Batubara. Bandung: Lubuk Agung.

[2] Arsyad, Azhar. 2014. Media Pembelajaran. Depok: RajaGrafindo Persada

[3] Marsudi, Ditjeng. 2011. Pembangkitan Energi Listrik. Jakarta: Erlangga

[4] Pusat kurikulum dan Perbukuan. 2015. Panduan Rapat Kerja Pelatihan dan Penilaian Buku Nonteks

[5] Republik Indonesia. 2008. Peraturan Menteri Pendidikan. Jakarta: Sekertariat Negara

[6] Rofiah, Aan. 2015. Pengembangan Buku Pengayaan Pengetahuan Berbasis Kontekstual PadaMateri Optik. Jurnal SNF, 4, 1-4.

[7] Sukandarrumidi. 2006. Batubara dan Pemanfaatannya. Yogyakarta: Gajah Mada University Press 